\title{
Investigative Journalism in Ghana, Challenges and Ethical Contentions
}

\author{
Isaac Bisilki (Correspondence) \\ Department of Communication Studies, University of Cape Coast, Ghana
}

Tel: 233-503-600-643.E-mail: bisilkibaba@gmail.com; bisilkibaba@yahoo.com

\author{
Richard Odomako Opoku \\ Kwame Nkrumah University of Science and Technology \\ Institute of Distance Learning, Kumasi, Ghana
}

Tel: 233-246-190-639. E-mail: richprezz@yahoo.com

\begin{abstract}
Received: August 30, 2018 Accepted: October 22, 2018 Published: October 25, 2018
doi: 10.5296/jsss.v6i1.13823 URL: http://doi.org/10.5296/jsss.v6i1.13823
\end{abstract}

\begin{abstract}
This paper set out to highlight an aspect of journalism, investigative journalism, by exploring the areas of ethical contentions and challenges that confront its practitioners in Ghana. Using in-depth interviews, the data collected revealed that investigative journalism remained a risky venture in Ghana. Legal suits and death threats constituted the dangers faced by investigative journalists. Based on the findings, the study recommends strong institutional support and capacity building for this category of journalists as well as collaborations among practitioners in their projects.
\end{abstract}

Keywords: Ghana's media landscape, Role of journalism, Investigative journalism

\section{Introduction}

The media is described as the fourth estate of the realm. This is due to the important role it plays in society. Journalists are therefore referred to as watchdogs of society because they monitor and guard policymakers' actions (Knuut et al., 2015) and track other people in authority to ensure morality is respected to the benefit of all. Ghana's recognition of the role of the media is evident in article 21 of the 1992 Constitution, which guarantees press freedom. 
However, journalists, just as practitioners of other professions, are bound to face some challenges that will impact negatively on the performance of their duties. The nature and degree of these challenges will depend on the environment (country) and its legislation on journalism. For instance, practitioners may come into friction with the laws that define the scope of their practice, or the ethics that guide their conduct in the performance of their duties. Owusu (2011) identified wanton ethical breaches as a major problem in the Ghanaian press, but Stetka and Ornebring's (2013) study on the autonomy of investigative journalism in Central and Eastern Europe discovered that the region's news organisations had a problem of finance, due to less-developed advertising markets. Whilst it is rare to find any study on the topic under investigation in Ghana, general records show that journalists who breached Ghana's Criminal Libel and Seditious Laws in the military era (prior to the introduction of the 1992 constitution) suffered severe consequences: imprisonment, heavy fines, etc.

Ghana's fledging democracy is receiving impetus from its free media landscape emboldened by the repeal of its Criminal and Seditious Libel Laws in August 2001. The repeal of this law did not only guarantee press freedom, but also accelerated the proliferation of news media outlets (Owusu, (ibid). This development certainly comes with its own ramifications, whether journalists'unethical conduct, as identified by Owusu (2011), has a direct link with the repeal of the Criminal Libel Law.

A recent observation, which underpins this study, is the siege on investigative journalists Anas Aremeyaw Anas of the Daily Searchlight newspaper and Manasseh Azure Awuni of $J o y F m$, all in Ghana. Their investigative reports on corruption in the public sector, have not only received public applause, but also faced legal suits from the affected persons. These suits do not only challenge the facts of the investigations; they also seek to pin down the approach used in investigative work.

The issue of methodology employed by investigative journalists remains a big debate in Ghana. However, this contention is deficient of the aspect of challenges that constrain investigative work. While there is extensive research on journalism in Ghana, the topic area being investigated is underexplored. Investigative journalism has not been given scholarly attention after over a decade of the repeal of the Criminal and Seditious Libel Laws. This study sought to fill this gab by exploring first-hand information from investigative journalists on the challenges they face. Specifically, the study focused on answering the questions (1) What are the information-gathering challenges facing investigative journalists in Ghana? (2) What ethical contentions arise in their investigations? (3) What is the extent of ethical breaches in their investigative works?

\section{Present Media Landscape in Ghana}

Ghana, at present, can boast of a more serene media landscape as compared to some other African countries. The media landscape became conducive with the repeal of the country's Criminal Libel Law in August 2001, which hitherto restricted press freedom (Owusu, 2011). Despite this freedom, the media seems to be overstepping its boundaries. Concerns are being raised about why ethical breaches are on the ascendancy. This, according to Owusu, can be attributed to the repeal of this law that inadvertently paved the way for irresponsible 
journalism (ibid). The ensuing outcry has resulted in many calling for a restoration of this law to bring sanity to the system. This was affirmed by Kabral Blay-Amiheri, the then Chairman of Ghana's national Media Commission (NMC): "The same society that voted for the freedoms of the media is speaking out loud today that journalists have to be held in check". The situation exacts some scholarly enquiry, especially at the time investigative journalists are faced with ethically-driven criticisms.

\section{Role of Journalism}

The contribution of journalism to national development cannot be overemphasised. Although there is contention over the appropriate definition of journalism, Lacy and Rosenstiel (2015) posit that journalism is "the serial presentation of information and conversation about public events, trends and issues distributed through various media with the primary purpose of informing, entertaining and connecting citizens in communities" (p. 6). This definition highlights one important feature of journalism: fostering social cohesion in society through the distribution of information to inform and entertain. But journalism's aim to convey information is argued to be the most important function of all (Knuut et al., 2015). Information can therefore be described as the trading currency of journalism. The watchdog role of journalists thrives on careful gathering of facts to guard policy makers' actions (ibid) as well as its appropriate distribution to ensure the public is well informed.

\section{Investigative Journalism in Ghana}

Investigative journalism is defined as a form of journalism in which journalists deeply investigate a single topic of interest, such as serious crimes, political corruption, or corporate wrongdoing (https://en.wikipedia.org/wiki/Investigative_journalism). However, in her manual: "Ten Steps to Investigative Journalism, Fleeson (1998) argues that the scope of this definition is rather narrowed as investigative journalism is not only about corruption and crime, but also encompasses stories that demystify how systems work or fail, or construct a complex event.

One of the perceived challenges of investigative journalism, as pointed out by former Chairman of Ghana's National Media Commission Kabral Blay-Amihere is the ownership of media outlets by politicians and their surrogates, a situation he believes "does a lot to affect the integrity of the media" (Daily Graphic, October 11, 2018, p. 3). He said this during the opening ceremony of the West Africa conference on Investigative Journalism in Accra. Despite this view, he noted the contribution of Investigative journalism to Ghana's development: "The work of Anas (most prominent investigative journalist in Ghana), for instance, has caused football to reinvent itself. We need investigative journalists to ensure that citizens enjoy the fruits of their resources and taxes" (ibid, p. 3). In recent times, Ghana has witnessed a new wave of investigative reporting. These reports, mainly on corruption, have ushered interesting debates on what constitutes best methodologies to investigations. Journalists involved in investigative work have faced several legal suits in recent times because perceived wrongful approach to investigations. This debate fails to touch on the aspect of challenges that impede investigative work. This paper feeds into this debate, by presenting practitioners' experiences on the challenges to proffer measures that will enhance 
investigative reporting.

\section{Ethical Considerations in the Study}

Researchers face many ethical issues that surface during data collection in the field and in analysis and dissemination of qualitative reports (Creswell, 2007). Lipson (1994, cited in Creswell, 2007), groups ethical issues into informed consent procedures; deception or covert activities; confidentiality toward participants, sponsors, and colleagues; benefits of research to participants over risks; and participant requests that go beyond social norms. According to the ethical guidelines of the Social Research Association (SRA), researchers have obligations towards the subjects of study and therefore, must "strive to protect subjects from undue harm arising as a consequence of their participation in research" (SRA, 2003). The main ethical concern for this study was the issue of confidentiality. The researchers put measures in place to ensure that the privacy and confidentiality of respondents were not breached. The objective of the study was demystified to respondents and all their responses were treated with strict confidentiality. At no point in this study or any related activity did the researchers disclose names or gave hints about the identity of respondents. Where necessary, pseudonyms rather than real names were assigned and used in this study.

\section{Conflict of Interest}

We declare that there is no conflict of interest with regard to the publication of this paper.

\section{Methodology}

Data for this study was collected using face-to-face in-depth interviews. This is probably the most widely used method in qualitative research (Bryman, 2008), and an indispensable way to probe phenomena such as journalistic attitudes and perceptions. One cannot understand human actions without understanding the meaning that participants attribute to those actions - their thoughts, feelings, beliefs, values, and assumptive words. The researcher, therefore, needs to understand the deeper perspectives captured through face-to-face interaction (Berger, 2010; Marshall \& Rossman, 2010). In this study, two leading and award-winning Ghanaian investigative journalists were asked open ended questions to enable them freely and better express their views and perceptions about investigative journalism. The selection of respondents was done by means of purposive sampling, settling on respondents based on their relationship and knowledge on investigative journalism (Bryman, 2008), and whose responses would best provide relevant data for analysis. An important criteria for selection were that respondents should be recognised members of the Ghana Journalists Association (GJA) and practising investigative journalists for not less than three years.

\section{Data Analysis}

The thematic analytical approach was used to analyse the field data. Through this process, the data was transcribed, described and narrated. The audio recordings were played over several times to enable the researchers to capture exactly what the respondents said. Data was transcribed by typing text on the laptop and listening to recordings over and over again in order to obtain familiarity and generate their meanings. The responses were grouped 
according to the specific theme at hand, from which issues of similarities and contrasts were derived and narrated. Direct quotations were used to give credence to the interpretive write-ups. According to Goodwin (2010), qualitative results are presented not in terms of statistical calculations, but as analytical narratives that summarise the research's main outcomes.

\section{Results and Discussion}

All participants of this study were males who had more than three years of professional experience in investigative journalism. All of them were members of the GJA. The male dominance in the sample reflected the real situation of investigative journalism practice in Ghana, as majority of investigative journalists in the country are males. Participants' years of experience in investigative reporting indicated that they had depth of knowledge and practical experience which were relevant to the objectives the study sought to achieve.

\section{Relevance of Investigative Journalism}

Discussing the relevance of investigative journalism, all respondents agreed that investigative journalism was essential to the well-being and development of society. They stressed that investigative reporting had the potential to promote accountability and expose corruption, scandal and other wrongdoings that impede the development of a society.

"You are looking at holding those in power to task, exposing the ills of society, giving a voice to the voiceless not in the conventional way, but in a different dimension where you want to go deep down and tell the story yourself irrespective of the risk attached to it," Respondent 1.

Another respondent said: "Investigative journalism is key in every nation's development because that is where journalists try to expose certain issues relating to human life and society in general. So it becomes interesting when investigative journalists, for instance, expose issues on social rot and all spheres of life be it spiritual, physical, social, educational aspects, " Respondent 2.

The views expressed by participants on the relevance of investigative journalism are collaborated by several scholars. Feldstein (2006), for instance, emphasises the unique objective of investigative journalism - unearthing wrongdoings that affect public interest. Investigative journalism seeks to expose unethical, immoral and illegal behaviour by government officials, politicians as well as private citizens (Kovach \& Rosenstiel, 2007), and constitutes an essential instrument to make accountability occur and give voice to the voiceless (Downie \& Kaiser, 2002). These views are not surprising as the whole concept of investigative journalism goes beyond the usual news coverage and press conferences, by seeking to unearth malfeasance and wrongdoings that hamper the development of a society.

Linking the relevance to why respondents are pursuing investigate journalism, they shared similar reasons - the passion to unearth wrongdoings and promote societal development. Respondents admitted that they get satisfaction when their investigations make impact, especially when authorities respond to their investigations by taking steps to punish wrongdoers or find solutions to problems reported. 
"The passion generally has to do with me wanting to do in my own little way, fighting injustice in the society," Respondent 1.

"What drives me is actually the passion to bring to the fore the ills in the society, bring to the fore the people who are making the nation to lose a lot of money, and to bring to the fore the harm that is caused to the environment, to our waters and every other thing that has to do with human life," Respondent 2.

\section{Sources of Ideas and Information for Investigative Reporting}

Sources of ideas for investigate work varied from respondent to respondent. While some sources were same, respondents also had different sources where they got ideas to start their investigative work.

"Some of the ideas come from observation... and [hints] from network of sources. So you have people approaching you with documents bordering on illegality, corruption and wrongdoing," Respondent 1.

"I get my ideas from friends and through reading. I don't get tip offs from organisations although some of my colleagues do, so I do everything myself. I have to go on the ground myself, surveying and monitoring," Respondent 2.

Respondents' sources of ideas largely depended on whether they were affiliated to a media organisation or worked as a freelance, as well as the direction or focus of respondents' investigative work. The sources of ideas and information of respondents are not different from sources used by many investigative journalists. In a study by Valiante (2013), investigative journalists, in addition to the sources outlined by respondents, also interact with whistleblowers to get information for their investigative work.

To facilitate access to these sources of information however, one respondent highlighted that credibility and branding were critical.

"Once you do a good job, you begin building a database of sources. So they know that if I have this [information], this is the best man to execute this job for me. So that's one. There are people because you have built a certain brand, they contact you through others," Respondent 1.

Closely linked to the sources of information is the technique used to gather information. Respondents elaborated on the techniques that they use to gather information for investigative work. They mentioned that the techniques used to gather information for investigative reporting were same techniques used in conventional journalism, including observation and participation, interviewing, researching, soliciting for expert opinions and other things to solidify conclusions on an investigative work. Respondents however, added that investigative journalism involves a lot of extra work.

"Investigative journalist must do some research and in-depth study of the issue, get reliable sources and make sure the facts are correct," Respondent 1. 
This view is supported by Aucoin (2005) and Gaines (1998) who said that investigative journalism takes a comprehensive, exhaustive look at issues. Through this conceptualization, reporters assumed their information searching as some kind of investigation because it involves extra work and extra effort. Reporters' enterprise is very important in gathering, sorting information, building patterns and connecting dots to reveal something of public importance (Aucoin, 2005; Gaines, 1998).

\section{Subterfuge (Hacking of Phones/Computers and Concealed Recording)}

Respondents mentioned that subterfuge was one distinguished technique employed to gather information. Respondents agreed that the use of subterfuge was controversial, but was sometimes unavoidable in investigative journalism. They suggested that such tactics and methods could be used only when an open approach would not work.

"Subterfuge is the last approach. Recording people secretly is the last approach. So I will only record you secretly as the last option," Respondent 1.

The mention of subterfuge raised thorny ethical issues about individual's rights to privacy and human dignity, which are guaranteed by both the 1992 Constitution of Ghana and the Ghana Journalists Association (GJA) Code of Ethics. But respondents argued that subterfuge was permitted if done in the public interest.

“... if is in the public interest, it doesn't breach anything. In other jurisdictions yes, it may not hold water but this is Ghana. Once it is in the public interest, you do it," Respondent 1.

"It's not too good to secretly record people without their permission, but if the national interest is more than the individual interest in it, then certainly you have to go undercover and record secretly," Respondent 2.

Indeed the GJA Code of Ethics cautions journalists against using discreet and clandestine approach to gather information, but provides a caveat. Article 13 of the Code of Ethics states that journalist shall: "obtain information, videos, data, photographs and illustrations only by honest, straightforward, fair and open means - unless otherwise tampered by public interest considerations."

The use of subterfuge is not new - it is common in investigative journalism. Davies (2008) terms phone and computer hacking and concealed recordings as the "dark arts" of journalism, while Sadle (2011) agrees that subterfuge remains the most controversial method investigative journalists use in gathering information. Therefore, while subterfuge could be considered as a breach of code of ethics, a journalist posing as someone else or using other kinds of subterfuge is not breaching the code if the investigation is justified by a sufficient public interest.

\section{Protection of News Sources}

Another ethical issue that strongly came up in the study was the protection of news sources. This is another controversial issue, and here, the researchers sought to know the circumstances that could make participants to disclose the identities of their news sources. 
All respondents strongly held that under no circumstances would they reveal the identities of their sources.

"Under no circumstances [will I disclose my news source] because the person has entrusted a certain trust in you that this is a wrongdoing that I have cited work on it. The person's life is on the peril if you reveal it. The person's job security is on the line if you reveal it. Even societal confrontations going against the norms will play against the person if you reveal his identity so there's no point in revealing your source and I don't remember revealing my source and even if I'm arrested, I will still not reveal my source. It's a non-starter', Respondent 1.

"No way, there is no instance that you have to do that [reveal the identity of your source]. It's not permitted. Ethically it's not good. And even humanly or in relationship terms, it's not good to do that because when you do that, you find it difficult to get information the next time because then people will know that it's this journalist who divulged his source identity. So there's no way in investigative journalism that you have to give off the names or the identities of your sources," Respondent 2.

Respondents' views are backed by the GJA Code of Ethics which guarantees the protection of confidential sources of information (Article 14). Their views further conform to the views of a number of scholars. If a journalist exposes the identity of confidential sources of information "it is reasonable to expect that in the future, informants who for one reason or another need to remain in secret will be reluctant to come forward to divulge what they know"' (Jacquette, 2007).

Davies (2008) shares similar view and says whistle-blowers often "reveal something that is vital to the public interest: the sort of thing that politicians conceal. They have the right to be protected."

Coulter (2005) outlines extensive reasons for protecting the identities of news sources: "The fundamental ethical principle of journalism is that we have a moral imperative to give a guarantee of anonymity to genuine confidential sources providing bonafide information. There can be no transparency in the trust that our sources must have in us as professional journalists. If we sacrifice that trust, we betray our credibility as reporters of the truth" (Coulter, 2005).

\section{Challenges Faced by Investigative Journalists}

Aside the controversial ethical issues discussed in this study, investigative journalists face a myriad of challenges considering the risky nature of their work. In order to delve deeper into the constraints that investigative journalists face, respondents were asked to share their challenges on the field. In unison, all the participants indicated that violent confrontations by affected persons, legal suits and issuance of death threats, as well as trailing by subjects and phone tapping were some of the general challenges they face.

"You have people writing writ of sermons to you that they will sue you in court... in one of my investigations, my recorder was seized by the man and was threatening to assault me. He 
tried to delete the sounds [from the recorder], but he was unable to do so. Up till now, he still has the recorder," Respondent 1.

“... I did some investigations and after I started showing [on TV], a lot of calls came. Two of them [affected persons] brought court sermons. Some called to threaten me that if I don't pull it down they will pray over me and invoke the spirit of the gods to come and attack me," Respondent 2.

The challenges outlined by respondents appear to be widespread and common occurrences in investigative journalism globally. Bruce Shapiro (2003) observes that the work of investigative reporters has historically so profoundly threatened the accepted order that many journalists were jailed, beaten, indicted, or threatened for their exposés, while (Downie \& Kaiser, 2002) ask news organisation to brace for possible legal action against them.

The OECD Survey on Investigative Journalism asked journalists to rate how safe they felt reporting on corruption cases, most respondents (35\%) indicated that they felt moderately safe. Journalists were most concerned about threatened or actual legal action, in the form of civil suits for libel, or criminal prosecution for defamation or publishing classified information. Some referred to baseless legal actions being launched to intimidate journalists, which nevertheless took time to resolve and involved significant legal and psychological cost. Other concerns included attacks on professional credibility and political retaliation. Some journalists had received death threats and mentioned colleagues who had been killed for their work investigating and reporting on corruption (OECD Survey on Investigative Journalism, 2017).

According to Transparency International's Corruption Perception Index 2017, 368 journalists have been killed since 2012 while pursing stories. Of those 368 journalists, one in five killed worldwide were investigating corruption-related stories. Analysis from the 2017 Index also indicates that countries with the lowest protection for press and NGOs tend to have the worst rates of corruption. There is however, some consolation in that respondents are fully conscious of these dangers and take precautionary measures to avoid them during their investigations.

"I always believe that your mistake means your death so you make sure that you reduce your mistakes. Once you realised that you have been compromised, just get out of the scene. Don't try to be a hero you will die," Respondent 1.

Another widely reported challenge that investigative journalists face is the frequent attempts by affected persons to bribe investigative journalists to censor their investigations. While all respondents haven't' had that experience yet, they did not rule it out as a practice happening in the profession.

“To say it doesn't exist will be false. They always do find nice ways but once you don't buy into the bait, they don't go ahead. There are several stories I have investigated the sources have told me that we met a lot of journalists, we gave them the information, they just went and took money and then the story never came out. But you need to build a certain brand so there are certain stories I have followed the sources contacted certain people and they were 
like if it's this person just forget it just be honest and tell him your own side. It is in your own interest," Respondent 1.

"So far I will say no. Nobody has come to bribe me to stop investigating him or her. But I'm sure the current one that I'm doing people will actually come but before they will even know it will be in public already, " Respondent 2.

On the issue of funding, respondents views were split. While one respondent indicated that funding was not a problem because of the financial backing he received from his organisation, the other respondent expressed that funding was a critical challenge.

"Funding is not a challenge, because that's one good thing about [my organisation organisation name omitted]. Once you set out to investigate, they give you a budget for it, so you draw a budget of all that is needed and then the company gives you the money to go and investigate," Respondent 1.

Respondent 1 view is supported by a research work by Kaplan (2008) where overwhelming majority of investigative journalists $(81 \%)$ reported that they received organisational support for their investigations. These findings are comforting since investigative reporting is usually tedious, time-consuming and dissipating, as well as a risky venture that requires full organisational support for reporters to make meaningful impacts.

On the other hand, Respondent 2 stated that: "It is always difficult to get funding for some of my projects. What I do is that normally, I do corporate documentaries for some organisations so the monies I get from that I use a percentage of that to do my social works that's my investigations and documentaries."

The sharp contrast by respondents on the issue of funding gave a panorama view of the realities that exist between affiliated and independent investigative journalists. While investigative journalists affiliated to media organisations are likely to get financial support and receive other benefits to carry out investigations, independent journalists do not have readily available financial support to conduct their investigations. The constraints of freelancers are further compounded due to a confluence of factors including trust.

"As a freelance journalist, you find it difficult to get support when you need it because people don't trust you. They think that you are just coming to make money from them. When I needed expert views in one of my investigations, I overheard the experts passing a comment that he's a freelancer so he's looking for money. Sometimes, it's even difficult to get information for your investigations from the very people who have promised you," Respondent 2.

The 2017 OECD Survey on Investigative Journalism also admitted that freelance or independent journalists were most exposed to threats and attacks; those who worked in large media outlets or in large cities felt more protected. But Respondent 2 believes that in spite of the peculiar challenges that independent journalists face, "people are likely to recognise and take you serious when you build trust over time, especially when your investigations start showing on $T V^{\prime \prime}$. 
Respondents, however, were unanimous that although a challenging and risky venture, investigative journalism is a rewarding enterprise.

"Investigative journalism is rewarding when you know that your story has made an impact, your story has changed the policy, your story has gotten someone who might hurt a child or something, someone who is abusing the system in prison," Respondent 1.

Respondent 2 similarly expressed: "Investigative journalism is risky. You can lose your life, you can lose your credibility, for instance, if proper information is not given to you or you don't take proper care in handling the information that is given to you. But you see there is inner reward especially when your story makes an impact."

\section{Improving investigative Journalism in Ghana}

Respondents provided some remarkable suggestions on how to improve investigative journalism in Ghana. They, for instance, stressed the significance of collaboration in investigative journalism.

"It is cost-effective in collaborating in investigative journalism. Sometimes it's an issue with expertise, not everyone is good at going undercover so may be if your colleague realises that you can do undercover better than he can, he collaborates with you so that you handle the undercover part and then he handles maybe the document part," Respondent 1.

"I collaborate with other reporters a lot. Sometimes, I even engage people who are not necessarily journalists or investigative journalists. They are just ordinary people who help us in our investigations especially when it comes to tracking some people because you cannot be at all the places all the time," Respondent 2.

The International Consortium of Investigative Journalists (ICIJ) investigations have for instance, involved more than 380 journalists working on six continents in 30 languages, highlighting the importance of collaborative networks for investigative journalists working on especially, complex cross-border investigations (OECD Survey on Investigative Journalism, 2017).

Respondents also expect the GJA to play its role by "promoting higher professional standards, defending press freedom and facilitating partnerships among journalists".

"There should be a lot of training and capacity building in investigative journalism. Adequate resource should be earmarked to investigative journalism in the country so that more wrongdoings can be exposed, Respondent 2 added.

\section{Conclusion}

Overall, literature supports participants' views on the concept of investigative journalism despite few different perspectives offered by participants that relate closely to values and factors influencing their practice. The findings have revealed that investigative journalism plays a crucial role in the fight against corruption and other societal vices. The strengthening of investigative journalism is vital for improving the quality of Ghana's democracy as investigative reporting remains central to the creation and consolidation of democratic 
principles, including promoting accountability. The achievement of this goal requires strong and sustained commitment from news organisations, the Ghana Journalists Association and the government. Effective press freedom, open data and access to information and protection for whistleblower are essential to enable free and credible reporting. The government must make press freedom and the protection of journalists, and their sources, a priority, as the right to professional secrecy gives credibility to journalists and their sources. There is the need to strengthen collaborations among investigative journalists and organisations to sustain healthy levels of investigative journalism. The findings of this study underpin the need for strong ethics in investigative journalism. The existence of workable code of ethics and strict adherence to ethical standards are indispensable for promoting fair, balance, accurate and credible reporting.

\section{References}

Aucoin, J. L. (2005). Evolution of American Investigative Journalism. Columbia: University of Missouri Press.

Berger, A. A. (2010). Media and communication research methods (2nd ed.). Thousand Oaks, CA: Sage.

Bryman, A. (2008). Social Research Methods (3rd ed.) New York: Oxford University Press. https://doi.org/10.1080/13645570701401644

Creswell, J. W. (2007). Qualitative Inquiry\& Research Design: Choosing Among Five Approaches (2nd ed.). USA: Sage Publications, Inc.

Coulter, J. (2005). The Moral Reason Never to Tell. British Journalism Review, 16(1), 65-69. https://doi.org/10.1177/0956474805053363

Davies, N. (2008). Flat Earth News: An Award Winning Reporter Exposes Falsehood, Distortion and Propaganda in the Global Media. London: Chatto and Windus.

Downie, L., \& Kaiser, R. (2002). The News about the News: American Journalism in Peril. New York: Alfred A. Knopf.

Feldstein, M. (2006). A Muckraking Model: Investigative Reporting Cycles in American History. Press/Politics, 11(2), 1-16. https://doi.org/10.1177/1081180X06286780

Fleeson, L. S. (1998). Ten Steps to Investigative Reporting. Retrieved October 14, 2018 from https://ijnet.org/en/content/10-steps-investigative-reporting-english

Gaines, W. C. (1998). Investigative Reporting for Print and Broadcast (2nd ed.). Chicago: Nelson-Hall.

Goodwin, C. J. (2010). Research in psychology methods and design (6th ed). New Jersey: John Wiley and Sons.

Jacquette, D. (2007). Journalistic Ethics: Moral Responsibility in the Media. Upper Saddle River, NJ: Pearson Prentice Hall. 
Kaplan, A. D. (2008). Investigating the Investigators: Examining the Attitudes, Perceptions, and Experiences of Investigative Journalists in the Internet Age. Faculty of the Graduate School of the University of Maryland, College Park.

Knuut et al. (2015). Media Guide: Practice and Ethics of Journalism for Adults. Retrieved October 10, 2018, from https://mediaguide.fi/wp-content/uploads/2016/09/media_guide _eng_painoversio_final.pdf

Kovach, B., \& Rosenstiel, T. (2007). The Elements of Journalism (Rev. ed.). New York: Three Rivers Press.

Marshall, C., \& Rossman, G. B. (2010). Designing qualitative research (5th ed.) Thousand Oaks, CA: Sage Publications.

OECD. (2018). The Role of the Media and Investigative Journalism in Combating Corruption, www.oecd.org/corruption/The-role-of-media-and-investigative-journalism-in-combatingcorru ption.htm

OECD. (2017). Whistleblowers and Whistleblower Protection in the Detection of Foreign Bribery, OECD Publishing, Paris. Retrieved from www.oecd.org/corruption/the-detection -of-foreign-bribery.htm

Owusu, W. Y. (2011). The Ghanaian Media Landscape: How unethical practices of journalists undermine progress. Retrieved October 14, 2018, from https://reutersinstitute.politics.ox.ac.uk/sites/default/files/research/files/The\%2520Ghanaian\% 2520Media\%2520Landscape\%2520How\%2520unethical\%2520practices\%2520of\%2520jour nalists\%2520undermine\%2520progress.pdf

Sadle, P. (2011). Last Edition of News of the World Sells Fast in London'. Retrieved from http://www.reuters.com/article/2011/07/10/us-newscorp-newsoftheworldidUSTRE7691LS20 110710

Shapiro, B. (2003). Shaking the Foundations: 200 Years of Investigative Journalism in America. Nation Books.

Social Research Association (SRA, 2003). Ethical Guidelines. Retrieved from http://www.the-sra.org.uk/documents/pdfs/ethics03.pdf.

Transparency International, "Digging deeper into corruption, violence against journalists and active civil society" $21 \quad$ February 2018, https://www.transparency.org/news/feature/digging_deeper_into_corruption_violence_agains $\mathrm{t}$ journalists

Valiante, G. (2013). Investigative Journalism in Montreal: “A Golden Age." Concordia University Montreal, Quebec, Canada.

What is Investigative Journalism? Retrieved 14th October 2018 from http://sand-kas-ten.org/ijm/Chapter_1.pdf 


\section{Copyright Disclaimer}

Copyright for this article is retained by the author(s), with first publication rights granted to the journal.

This is an open-access article distributed under the terms and conditions of the Creative Commons Attribution license (http://creativecommons.org/licenses/by/3.0/). 